\title{
Convective and Microwave Drying of Mushrooms (A.bisporus and P.ostreatus)
}

\author{
Özge SÜFER ${ }^{1}$, Yasemin ÇELEBI SEZER ${ }^{1}$, Fuat BOZOK ${ }^{2}$
}

${ }^{1}$ Osmaniye Korkut Ata University, Faculty of Engineering, Department of Food Engineering, Karacaoğlan Campus, 80000, Osmaniye-TURKEY.

${ }^{2}$ Osmaniye Korkut Ata University, Faculty of Science, Department of Biology, Karacaoğlan Campus, 80000, Osmaniye-TURKEY.

\begin{abstract}
Dried edible mushrooms are able to be consumed in soup and sauce recipes. Utilization of $A$. bisporus and $P$. ostreatus in food formulations could bring added value to these products. In this study, $A$. bisporus and $P$. ostreatus samples were dried at 60,70 and $80^{\circ} \mathrm{C}$ in conventional oven and at 180,360 and $600 \mathrm{~W}$ in a microwave oven until no weight changes were observed. Among 15 thin layer drying equations, Sigmoid model gave the best results after fitting the experimental moisture ratios. The effective moisture diffusivities of $A$. bisporus and $P$. ostreatus were in the range of $2.19068 \times 10^{8}$ $8.57569 \times 10^{-8} \mathrm{~m}^{2} / \mathrm{s}$ for convective, $1.92368 \times 10^{-7}-7.37349 \times 10^{-7} \mathrm{~m}^{2} / \mathrm{s}$ for microwave drying; $2.19068 \times 10^{-8}-1.20754 \times 10^{-7} \mathrm{~m}^{2} / \mathrm{s}$ for convective, $1.60293 \times 10^{-7}-6.09115 \times$ $10^{-7} \mathrm{~m}^{2} / \mathrm{s}$ for microwave drying respectively. The activation energies were calculated as $66.86 \mathrm{~kJ} / \mathrm{mol}$ and $12.64 \mathrm{~W} / \mathrm{kg}$ for $A$. bisporus and $83.25 \mathrm{~kJ} / \mathrm{mol}$ and $12.34 \mathrm{~W} / \mathrm{kg}$ for P. ostreatus.
\end{abstract}

Keywords: $P$. ostreatus, $A$. bisporus, mushroom, Drying, Mathematical modeling

\section{INTRODUCTION}

Edible mushrooms have specific flavors, textures and high nutritional value, hence they have been becoming favourite food materials all over the world $d^{1,2,3}$ and using in soup and sauce formulations. ${ }^{4}$ On the other hand, mushrooms are not only valuable food sources, but also having medicinal properties $^{5,6}$ due to containing various bioactive molecules like antioxidants, ${ }^{7,8}$ steroids, phenolics and terpenes. ${ }^{3-9}$ Studies demonstrated that 150 types of mushroom had the antioxidant potential. ${ }^{10}$

Drying is one of the oldest preservation methods of foods. Conventional drying is the most common technique and microwaves supply rapid moisture removal. Heat and mass transfer occur at the same time in this processes, ${ }^{11}$ thus some complexities could arise. In order to solve difficulties and understand the mechanism of dehydration, mathematical models could be helpful. Mathematical models are classified into three categories as empirical, semi-empirical and theoretical. ${ }^{12}$

The aim of this study was (i) to determine conventional and microwave drying kinetics of $A$. bisporus and P. ostreatus, (ii) to fit experimental drying data into 15 different mathematical models, (iii) to estimate effective moisture diffusivity of mushrooms, (iv) to calculate activation energies of samples.

\section{MATERIALS AND METHODS}

\section{MATERIAL}

A. bisporus and P. ostreatus were produced by using composts in Mushroom House of Osmaniye Korkut Ata University, Turkey. The mushrooms were cut into small pieces with a sharp knife manually, put onto glass petri dishes $(120 \times 17 \mathrm{~mm})$ and dried immediately after cutting. All experiments were performed in triplicate and continued until no changes were observed in weight
DOI: 10.5530/ijper.51.3s.54 Correspondence: Özge SÜFER,

Osmaniye Korkut Ata University, Faculty of Engineering, Department of Food Engineering, Karacaoğlan Campus, 80000, Osmaniye-TURKEY. Phone no:

00903288271000/3656

E-mail: ozgesufer@ osmaniye.edu.tr 
of samples. Initial moisture content of $A$. bisporus was $91.55 \pm 0.03 \%$ and P.ostreatus was $91.80 \pm 0.35 \%$ according to AOAC, $1990 .{ }^{13}$

\section{Drying}

A laboratory type natural convection oven (JSR, JSON250) was used for convective drying. Studied temperatures were 60,70 and $80^{\circ} \mathrm{C}$ and before experiments, the dryer was run idle for 5-6 min to reach target temperature. The weight of samples was determined in every 5 minutes manually by using a digital balance (Radwag, AS/X, Poland). The weighing procedure was not exceeded $10 \mathrm{~s}$.

A microwave oven (Arçelik, MD 574, Turkey) having 6 different power level was also installed. Studied power levels and weighing times were 180, 360 and $600 \mathrm{~W}$ and 60, 40 and 30 s respectively. Samples on petri dishes were placed on a rotating plate $(\mathrm{D}=245 \mathrm{~mm})$ in oven and the sample masses were defined as taking the petri out of system, weighing sample and then putting back into the oven. The measurement took about $10 \mathrm{~s}$ like in conventional drying.

\section{Mathematical modeling}

15 thin layer drying models called as; Lewis, ${ }^{14}$ Page, ${ }^{15}$ Modified Page, ${ }^{16}$ Henderson and Pabis, ${ }^{17}$ Logarithmic, ${ }^{18}$ Two-term, ${ }^{19}$ Midilli et al. ${ }^{20}$ Wang and Singh, ${ }^{21}$ Weibull, ${ }^{22}$ Parabolic, ${ }^{20}$ Cubic, $^{23}$ Thompson $^{24}$ Sigmoid $^{25}$, Rational ${ }^{26}$ and Vega Lemus ${ }^{27}$ were applied the moisture ratio data of samples. Moisture ratios MR were defined by the formula of $\mathrm{M} / \mathrm{M}_{0}$. M represents moisture $(\mathrm{g})$ at any time and $\mathrm{M}_{0}$ is the initial moisture (g) of sample. The highest determination coefficient $\mathrm{R}^{2}$ and the lowest Root mean square error RMSE and chi square $\chi^{2}$ levels ${ }^{28}$ were used for selecting the best model which described the drying phenomenon. All statistical analysis was done with the aid of Origin lab Pro 2016 software.

To calculate effective moisture diffusivities $\left(\mathrm{D}_{\text {eff }}\right)$, Fick's second law for cylinder geometry was accepted. ${ }^{11}$ On the other hand, Arrhenius type equation was valid for the activation energy $\left(\mathrm{E}_{\mathrm{a}}\right)$ of convective drying, however in microwave; this equation was modified by Dadali and Özbek, 2008. ${ }^{29}$

\section{RESULTS AND DISCUSSION}

\section{Drying kinetics}

All mushroom samples were dehydrated until no weight changes were observed. Drying times were $12 \mathrm{~h}, 8 \mathrm{~h}$ and $6.5 \mathrm{~h}$ at 60,70 and $80^{\circ} \mathrm{C}$ and $47 \mathrm{~min}, 23 \mathrm{~min}$ and $12 \mathrm{~min}$ at 180, 360 and $600 \mathrm{~W}$ for each type of mushroom respectively. When temperature/power increased, the drying time reduced. Same results were expressed by Doymaz, $2011^{12}$ in pomegranate arils, Vega-Galvez et al., $2009^{26}$ in red pepper and Tulek, $2011^{28}$ in oyster mushrooms as well.

\section{Mathematical modeling}

Thin layer drying models (semi-empirical) have been using for years to define dehydration behaviors of food materials, so in this research fifteen of them were fitted to experimental data and Sigmoid model gave the highest $\mathrm{R}^{2}$ and the lowest RMSE and $\chi^{2}$ values in all trials. The results of this model were given in Table 1. "k" represented drying constant (1/min) and "a", "b" and "c" were the constants. "d" term was not depicted in Table 1 because of closing to zero. Sigmoid model is not a common equation in available literature, but it identifies dehydration procedure very well compared to others. Süfer et al., $2017^{11}$ and Figiel, $2009^{25}$ also claimed the

\begin{tabular}{|c|c|c|c|c|c|c|c|}
\hline \multicolumn{9}{|c|}{ Results of sigmoid model } \\
\hline Sample & $\boldsymbol{R}^{2}$ & $\boldsymbol{X}^{2}$ & $\boldsymbol{R M S E}$ & $\boldsymbol{k}(\mathbf{1} \mathbf{m i n})$ & $\boldsymbol{a}$ & $\boldsymbol{b}$ & $\boldsymbol{c}$ \\
\hline A. bisporus $-60^{\circ} \mathrm{C}$ & 0.99962 & 0.00000 & 0.00143 & -0.06191 & 0.28717 & 0.75677 & 28.59153 \\
\hline A. bisporus $-70^{\circ} \mathrm{C}$ & 0.99985 & 0.00000 & 0.00176 & -0.03125 & 0.96911 & 0.27965 & 34.29353 \\
\hline A. bisporus $-80^{\circ} \mathrm{C}$ & 0.99965 & 0.00003 & 0.00451 & -0.02997 & 1.67795 & -0.16933 & 27.33148 \\
\hline P. ostreatus $-60^{\circ} \mathrm{C}$ & 0.99906 & 0.00001 & 0.00222 & -0.04860 & 0.33948 & 0.73236 & 26.95817 \\
\hline P. ostreatus $-70^{\circ} \mathrm{C}$ & 0.99992 & 0.00000 & 0.00114 & -0.02092 & 1.21862 & 0.23625 & 24.80393 \\
\hline P. ostreatus $-80^{\circ} \mathrm{C}$ & 0.99943 & 0.00004 & 0.00501 & -0.02384 & 2.18050 & -0.31211 & 15.21244 \\
\hline A. bisporus $-180 \mathrm{~W}$ & 0.99934 & 0.00001 & 0.00297 & -0.00210 & 0.94738 & 0.37656 & 315.43834 \\
\hline A. bisporus $-360 \mathrm{~W}$ & 0.99939 & 0.00002 & 0.00363 & -0.00421 & 1.00964 & 0.20757 & 312.97939 \\
\hline A. bisporus $-600 \mathrm{~W}$ & 0.99925 & 0.00003 & 0.00433 & -0.00721 & 0.99199 & 0.28247 & 136.64819 \\
\hline P. ostreatus $-180 \mathrm{~W}$ & 0.99743 & 0.00004 & 0.00506 & -0.00238 & 0.76058 & 0.38207 & 584.79122 \\
\hline P. ostreatus $-360 \mathrm{~W}$ & 0.99922 & 0.00002 & 0.00410 & -0.00684 & 0.65852 & 0.44874 & 250.41665 \\
\hline P. ostreatus $-600 \mathrm{~W}$ & 0.99735 & 0.00008 & 0.00706 & -0.00564 & 1.07520 & 0.20644 & 186.03805 \\
\hline
\end{tabular}


certainty of this mathematical expression. Other suitable models which described drying phenomena of mushrooms were Cubic and Parabolic models (data not shown).

The effective moisture diffusivities for $A$. bisporus $\left(\mathrm{E}_{\mathrm{a}}=66.86 \mathrm{~kJ} / \mathrm{mol}\right.$ and $\left.12.64 \mathrm{~W} / \mathrm{kg}\right)$ were $2.19068 \times$ $10^{-8} / 1.92368 \times 10^{-7}, 5.02252 \times 10^{-8} / 4.16763 \times 10^{-7}$ and $8.57569 \times 10^{-8} / 7.37349 \times 10^{-7} \mathrm{~m}^{2} / \mathrm{s}$; for P. ostreatus $\left(\mathrm{E}_{\mathrm{a}}=83.25 \mathrm{~kJ} / \mathrm{mol}\right.$ and $\left.12.34 \mathrm{~W} / \mathrm{kg}\right)$ were $2.19068 \times$ $10^{-8} / 1.60293 \times 10^{-7}, 4.16763 \times 10^{-8} / 3.67530 \times 10^{-7}$ and $1.20754 \times 10^{-7} / 6.09115 \times 10^{-7} \mathrm{~m}^{2} / \mathrm{s}$ at $60^{\circ} \mathrm{C} / 180 \mathrm{~W}$, $70^{\circ} \mathrm{C} / 360 \mathrm{~W}$ and $80^{\circ} \mathrm{C} / 600 \mathrm{~W}$ respectively. In higher temperatures/powers, increased moisture diffusivities were seen and diffusivities were comparably lower in conventional drying. Zogzas et al. ${ }^{30}$ indicated the $\mathrm{E}_{\mathrm{a}}$ values of foods were in range of $12.7-110 \mathrm{~kJ} / \mathrm{mol}$, hence levels for conventional drying were between in this gap. For microwave drying, there were no available data for comparison.

\section{CONCLUSION}

In this research, various drying methods and modeling of dehydration kinetics in A.bisporus and P.ostreatus were studied. Sigmoid model showed the best statistical outcomes in all samples and the moisture diffusivities of A.bisporus were always greater than the other. However, P.ostreatus had the highest $\mathrm{E}_{\mathrm{a}}$ in conventional drying.

\section{ACKNOWLEDGEMENT}

The authors are grateful to Osmaniye Korkut Ata University for supplying mushroom samples.

\section{CONFLICT OF INTEREST}

None

\section{ABBREVIATION USED}

M: Moisture content at any time (g water); Mo: Initial moisture content ( $\mathrm{g}$ water); MR: Moisture ratio; $\mathrm{R}^{2}$ : determination coefficient; RMSE: Root mean square error; $\mathrm{X}^{2}$ : Chi square; D eff: Effective diffusivity $\left(\mathrm{m}^{2} / \mathrm{s}\right)$; Ea: Activation energy $(\mathrm{kJ} / \mathrm{mol}$ and $\mathrm{W} / \mathrm{kg})$.

\section{REFERENCES}

1. Manzi P, Gambelli L, Marconi S, Vivanti V, Pizzoferrato L. Nutrients in edible mushroom, an inter-species comparative study. Food Chem. 1999;65(4): 477-482.

2. Zhang D, Frankowska A, Jarzynska G, Kojta AK, Drewnowska M, Wydmanska D, et al. Metals of king bolete (Boletus edulis) collected at the same site over two years. African J Agric Res. 2010;5:3050-5.
3. Islam T, Yu X, Xu B. Phenolic profiles, antioxidant capacities and metal chelating ability of edible mushrooms commonly consumed in China. LWTFood Sci Tech. 2016;72:423-31.

4. Ozen T, Turkekul I. Antioxidant activities of Sarcodon imbricatum wildly grown in the black sea region of Turkey. Phcog Mag. 2010;6(22):89-97.

5. Süfer Ö, Bozok F, Demir H. Usage of Edible Mushrooms in Various Food Products. Turkish J Agric Food Sci Tech. 2016;4(3):144-9.

6. Acharya K, Das K, Paloi S, Dutta AK, Hembrom ME, Khatua S, Parihar A. Exploring a novel edible mushroom Ramaria subalpina: Chemical characterization and Antioxidant activity. Pharmacog J. 2017;9(1):30-4.

7. Ganeshpurkar A, Rai G, Jain A P. Medicinal mushrooms: Towards a new horizon. Phcog Rev. 2010;4(8):127-35.

8. Dissanayake DP, Abeytunga D, Vasudewa NS, Ratnasooriya WD. Inhibition of lipid peroxidation by extracts of Pleurotus ostreatus. Phcog Mag. 2009;5(19):266-71.

9. Barros L, Baptista P, Ferreira ICFR. Effect of Lactarius piperatus fruiting body maturity stage on antioxidant activity measured by several biochemical assays. Food Chem Toxic. 2007;45(9):1731-7.

10. Madhanraj R, Eyini M, Balaji P. Antioxidant Assay of Gold and Silver Nanoparticles from Edible Basidiomycetes Mushroom Fungi. Free Radicals and Antioxidants. 2017;7(2):137-42.

11. Süfer Ö, Sezer S, Demir H. Thin layer mathematical modeling of convective, vacuum and microwave drying of intact and brined onion slices. J Food Process Preserv. In press 2017.

12. Doymaz I. Drying of Pomegranate Arils and Selection of a Suitable Drying Model. Food Biophy. 2011;6(4):461-7.

13. AOAC. Official method of analysis. Association of official analytical chemists (No. 934.06). Arlington, VA, 1990.

14. Bruce DM. Exposed-layer barley drying: Three methods fitted to new data up to $150^{\circ} \mathrm{C}$. J Agric Eng Res. 1985;32(4):337-47.

15. Page GE. Factors influencing the maximum rates of air drying shelled corn in thin layers (M.S. thesis). Purdue, USA: Department of Mechanical Engineering, Purdue University. 1949

16. White GM, Ross IJ, Ponelert R. Fully-exposed drying of popcorn. Transactions of the ASAE 1981;24:466-468.

17. Henderson SM, Pabis S. Grain drying theory. 1. Temperature effects on drying coefficients. J Agric Eng Res. 1961;6:169-74.

18. Togrul IT, Pehlivan D. Mathematical modelling of solar drying of apricots in thin layers. J Food Eng. 2002;55(3):209-16.

19. Henderson SM. Progress in developing the thin layer drying equation. Transactions of the ASAE. 1974;17(6):1167-72.

20. Sharma GP, Prasad S. Effective moisture diffusivity of garlic cloves undergoing microwave-convective drying. J of Food Eng. 2004;65(4):609-17.

21. Wang $C Y$, Singh RP. Use of variable equilibrium moisture content in modelling rice drying. Transactions of the ASAE. 1978;11(6):668-72.

22. Corzo O, Bracho N, Pereira A, Vasquez A. Weibull distribution for modelling air drying of coroba slices. LWT - Food Sci Tech. 2008;41(10):2023-8.

23. Dalvand MJ, Mohtasebi SS, Rafiee S. Determining the influence of drying conditions on EHD drying process. J Agric Bio Sci. 2012;7:396-401.

24. Thompson TL, Peart RM, Foster GH. Mathematical simulation of corn drying - a new model. Transactions of ASAE 1968;11(4):582-6.

25. Figiel A. Drying kinetics and quality of vacuum-microwave dehydrated garlic cloves and slices. J of Food Eng. 2009;94(1):98-104.

26. Vega-Galvez A, Di Scala K, Rodriguez K, Lemus-Mondaca R, Miranda M, Lopez J, et al. Effect of air-drying temperature on physico-chemical properties, antioxidant capacity, colour and total phenolic content of red pepper (Capsicum annuum, L. var. Hungarian). Food Chem. 2009;117:647-53.

27. Haghi AK, Angiz FZ. Heat and mass transfer in thermal drying of wool: A theoretical approach. In Proceedings of the $5^{\text {th }}$ Asia-Pasific Drying Conference. 2007;443-8.

28. Tulek Y. Drying kinetics of oyster mushroom (Pleurotus ostreatus) in a convective hot air dryer. J Agric Sci Tech. 2011;13:655-64.

29. Dadali G, Ozbek, B. Microwave heat treatment of leek: drying kinetic and effective moisture diffusivity. Int. J Food Sci Tech. 2008;43(4):1443-51.

30. Zogzas NP, Maroulis ZB, Marinos-Kouris D. Moisture diffusivity data compilation in foodstuffs. Drying Tech. 1996;14(10):2225-53. 


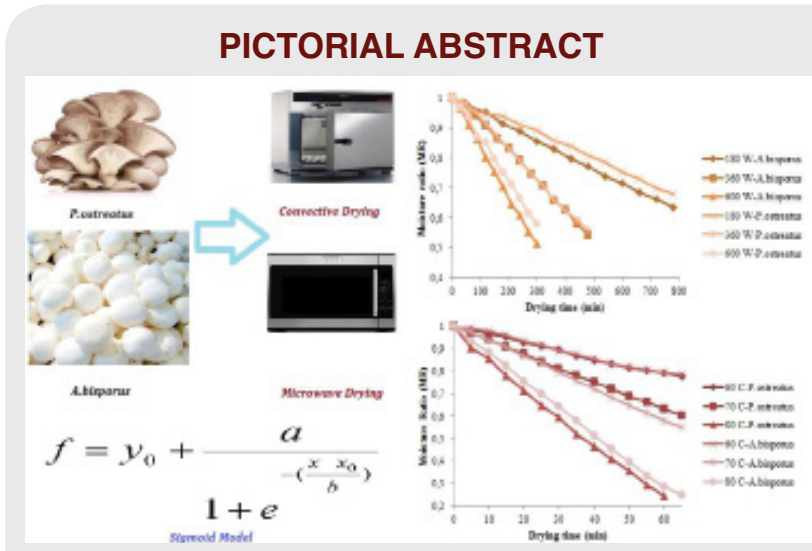

\section{SUMMARY}

- Drying kinetics of A.bisporus and P.ostreatus in conventional and microwave oven were investigated.

- Drying temperatures of mushroom samples were 60,70 and $80^{\circ} \mathrm{C}$ and power levels were 180,360 and $600 \mathrm{~W}$.

- Sigmoid model was the best for describing drying phenomena of all types of sample.

- Activation energy of A.bisporus was less than the other in conventional drying, however, P.ostreatus has the lowest value in microwave drying.

\section{ABOUT AUTHORS}

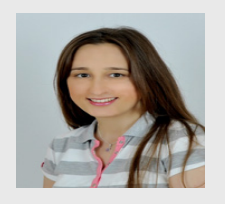

Özge Süfer: Is PhD candidate in the department of food engineering at University of Mersin and research assistant at Osmaniye Korkut Ata University in Turkey. She graduated from Ege University (Bachelor and Master), Turkey. Her studies have focused on drying of food materials.

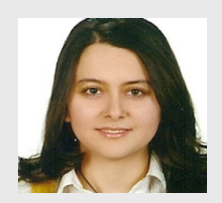

Yasemin Celebi Sezer: Is PhD candidate in the department of food engineering at University of Gaziantep and research assistant at Osmaniye Korkut Ata University in Turkey. She graduated from Ege University, Turkey (Bachelor). Her studies have focused on meat, meat products and packaging materials.

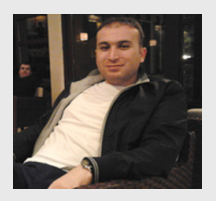

Fuat Bozok: is $\mathrm{PhD}$ and research assistant in the department of Biology at Osmaniye Korkut Ata University. He graduated from Erciyes University, Kayseri, Turkey (Bachelor). His studies focused on mushrooms, fungis, mycology and their antioxidant properties.

Cite this article: SÜFER Ö, SEZER YC̣, BOZOK F. Convective and Microwave Drying of Mushrooms (A. bisporus and p. ostreatus). Indian J of Pharmaceutical Education and Research. 2017;51(3)Suppl:S389-92. 